\title{
Genetolingvistična klasifikacija vzhodnoslovanskih jezikov
}

\author{
MATEJ ŠEKLI \\ Filozofska fakulteta Univerze v Ljubljani, Aškerčeva 2, in \\ Inštitut za slovenski jezik Frana Ramovša ZRC SAZU, Novi trg 4, \\ SI-1000Ljubljana,matej.sekli@guest.arnes.si
}

V prispevku je obravnavan nastanek posameznih vzhodnoslovanskih geolektov hierarhične stopnje jezika iz prvotne vzhodne slovanščine. Znotraj le-te sta se pojavili dve inovativni središči, in sicer severovzhodno (»rusko«) in jugozahodno (»ukrajinsko«), iz katerih sta se oblikovali ruščina in ukrajinščina, med njima pa na zahodnem obrobju prehodni geolekt beloruščina. Za vsak vzhodnoslovanski jezik so prikazane njegove definicijske lastnosti, ki ga razmejujejo znotraj vzhodne slovanščine in v razmerju do sosednjih jezikov, ter model njegove lingvogeneze.

The article attempts to classify East Slavic languages according to the model of their respective linguogeneses, focusing on the development of individual geolects from the original East Slavic. For an early stage of East Slavic two focal areas can be established, viz. North-Eastern East Slavic (Russian) and South-Western East Slavic (Ukrainian), the transitional area being occupied by Western East Slavic (Belorussian). The attempt is made to establish the defining characteristics which delimit the individual East Slavic idioms within the wider linguistic area and in relation to each other.

Ključne besede: genetolingvistika, geolingvistika, geolekt, genetolingvistična klasifikacija, primerjalno jezikoslovje, vzhodnoslovanski jeziki

Key words: genetic linguistics, geolinguistics, geolect, genetic classification, comparative linguistics, East Slavic languages

\section{Uvod}

Pozna praslovanščina (do ok. 800) se je po starejših popraslovanskih inovacijah razcepila na tri slovanske makrogeolekte (južna : vzhodna : zahodna slovanščina) ter hkrati znotraj le-teh na manjše geolekte (znotraj vzhodne slovanščine 
se je že zelo zgodaj pojavilo vsaj pet osnovnih starejših vzhodnoslovanskih geolektov). ${ }^{1}$ Vzhodno slovanščino kljub začetnemu divergentnemu izhodišču kot enotni geolekt povezujejo starejše in nekoliko mlajše splošnovzhodnoslovanske inovacije. Vzhodnoslovanski geolekti hierarhične stopnje jezika so se dokončno izoblikovali po mlajših nesplošnovzhodnoslovanskih inovacijah.

V prispevku je v prvem delu prikazano oblikovanje (sicer nekoliko neenotne) vzhodne slovanščine, $v$ drugem delu pa njen razcep na vzhodnoslovanske jezike.

\section{Oblikovanje vzhodne slovanščine}

\subsection{Starejše splošnovzhodnoslovanske glasovne značilnosti}

Starejše splošnovzhodnoslovanske glasovne značilnosti (arhaizmi in inovacije) se pojavljajo v vsej vzhodni slovanščini. Na osnovi primerjave z jezikovnim stanjem v južni slovanščini (tj. v stari cerkveni slovanščini) je mogoče sklepati, da so se najverjetneje izoblikovale že pred 2. polovico 9. stoletja, izpričane pa so šele od začetka vzhodnoslovanske pisne tradicije znotraj vzhodnoslovanske redakcije cerkvene slovanščine v 11. stoletju (nekatere sporadično že v Ostromirovem evangeliju (1056-1057) (dalje OE)), in sicer neposredno predvsem tiste značilnosti, ki niso (tudi) južnoslovanske, kot odmik od starocerkvenoslovanske jezikovne norme. ${ }^{2}$ Nekatere od njih so značilne za širši prostor, kot je vzhodnoslovanski, nekatere pa samo za vzhodnoslovansko jezikovno ozemlje.

\subsubsection{Starejše splošnovzhodnoslovanske in širše glasovne značilnosti}

Popraslovanske glasovne značilnosti, ki so značilne za vzhodno slovanščino in širše, so predstavljene glede na svoj zemljepisni obseg in posledično glede na to, kateri geolekti so se z njihovo prisotnostjo/odsotnostjo oblikovali (gledano s stališča pozneje izoblikovanih geolektov):

\footnotetext{
${ }^{1}$ Pričujoči prispevek je nadaljevanje obravnave genetolingvistične klasifikacije slovanskih jezikov v Šekli 2013a in 2013b. Na osnovi konstruktivnih pripomb prof. dr. Alenke Šivic-Dular in dr. Tijmena Pronka na prispevek v Šekli 2013b v diskusiji na mednarodni znanstveni konferenci »200-letnica rojstva Franca Miklošiča« v Ljutomeru 19. 11. 2013, za katere se diskutantoma iskreno zahvaljujem, je koncept obravnave problematike tu nekoliko dopolnjen. Poleg zemljepisne razširjenosti glasovnih inovacij znotraj makrogeolekta in nabora glasovnih inovacij, ki jih neki geolekt izkazuje, sta namreč (kjer je to mogoče) upoštevani tudi njihova relativna in absolutna kronologija. Tako sta za posamezni geolekt prikazani njegova glasovna struktura in njena geneza.

2 Nekatere vzhodnoslovanske glasovne značilnosti so sporadično dokumentirane že prej,

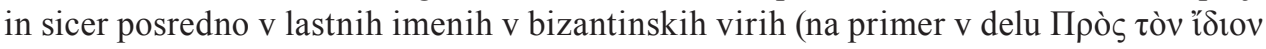
viòv P $\omega \mu \alpha$ vóv 'Svojemu sinu Romanu' = De administrando imperio 'O upravljanju cesarstva' (ok. 950) bizantinskega cesarja Konstantina VII. Porfirogeneta (vladal 913-959) (dalje KP).
} 
1) splošnoslovansko: psl. *öRC > sl. RaC (psl. *ördlo 'ralo' > vsl. pano > rus. ра́ло, brus. ра́ла, ukr. ра́ло; psl. *ölkотъjь 'lakomen' > vsl. пакомыи > rus. ла́комылй, brus. лако́мы, ukr. лако́мий) ${ }^{3}$

2) vzhodna in južna : zahodna slovanščina: a) psl. *ś > vsl. $s$ (psl. *xědzjb > *śédzjb 'siv'> vsl. cłaыn > rus. ceдóŭ, ukr. cidüü; psl. *vbxo > *vbśe 'vse'

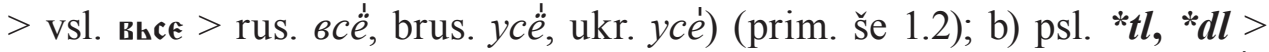
vsl. $l$ (psl. *pletlъ *pletla 'pletel/pletla (je)'> vsl. плєกъ ппєпа > rus. плёл плела́, brus. плёу пляла', ukr. плів плела'; psl. *vedlъ *vedla 'vedel/vedla (je)' > vsl. вєпъ вєла > rus. вёл вела́, brus. вёу вяла́, ukr. вів вела́; psl. *šidlo 'šilo' > rus. шилло, brus. шьлла, ukr. шилл); c) psl. “tn, *dn > vsl. $n$ (psl. *svbtnoti 'svitati se' > vsl. свьногти; psl. *vednoti 'veneti' > vsl. ваногти > rus. вяннуть, brus. вя่нуць, ukr. в’'янути); с̌) psl. *3> vsl. $z$ (psl. *kъnезь

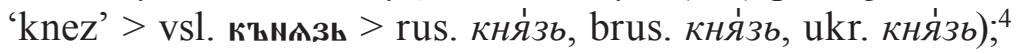

3) vzhodna in zahodna : južna slovanščina: a) psl. *oRC > vsl. $R o C$ (psl. *órvbnъjв 'raven' > vsl. ровьнъии > rus. роввный, brus. ро́вны, ukr. рівний; psl. *ôlkъtь 'laket' > vsl. покъть > rus. ло́коть, brus. ло́каць, ukr. ло́коть); psl. *eRC > vsl. ReC (psl. *êlbedb/*êlbędb 'labod'> vsl. пєвєаь > rus. ле́бедь (: лебяний), brus. ле́бедзь, ukr. ле́бідь); b) psl. *e/*脑 $>$ vsl. $\check{e}_{3}$ (psl. Gsg/ NApl *dušę/*dušě ${ }_{3}$ 'duše' > stcsl. norшa : vsl. norwt);

4) vsak en makroareal: a) psl. *pli, *bl, *mí, *ví > pl', $b l$ ', $m l$ ', $v l$ '(: zsl., V jsl. $p j$, bj, mj, vj) (psl. *zemĺa 'zemlja' > vsl. земкга > rus. земля, brus. зялля, ukr. земля); b) psl. *坼, *̌̌̆ $>$ vsl. пишталь (!) [piščalь] > rus. пища́ль, brus. пішчáль, ukr. пища́ль; psl. *drožži 'droži' $\rightarrow$ rus. дрожжжu, brus. дрожжджы, ukr. дріжджi);

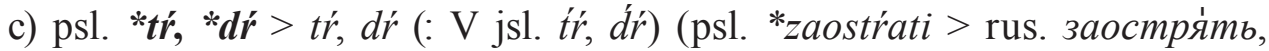
psl. *umodŕati > rus. умудрять : psl. *uxytŕati > stcsl. оүхыштргати, psl.

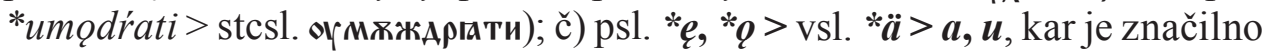
tudi za južno ter osrednjo zahodno slovanščino, tj. češčino in slovaščino ter lužiščino (psl. *desętb 'deset' > vsl. десать > rus. де́сять, brus. дзе́сяиь, ukr. де́сять; psl. *mфžь 'mož' > vsl. моүжь > rus. мужж, brus. му่ж, ukr. му’ж), kar je izpričano od sredine 10 . stoletja (*nejesytb $>$ vsl. мегасыты 'pelikan, jastreb' $\rightarrow N \varepsilon \alpha \sigma \eta ́ \tau$ (ime slapu na Dnepru), Asg m *vbrot́bjb > vsl.

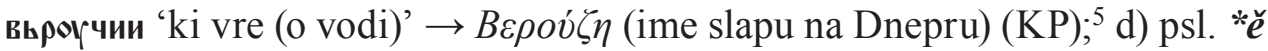

${ }^{3}$ Kjer to ni posebej navedeno, so za ponazoritev stanja v posameznih geolektih navedeni zgledi iz krovnih knjižnih jezikov.

${ }^{4}$ Poenostavitev zlitnika psl. $*_{3}>$ vsl. $z$ je torej splošnovzhodnoslovanska, oblike tipa nar. ukr. дзвізда́ so drugotne, nastale preko vmesne oblike z z (psl. *gvězda > vsl. *3vězda $>$ зв *zvопъ 'zvonjenje' > vsl. звөмъ > rus. звӧн, brus. звӧн, ukr. дзвін (IGRJ: 53).

${ }^{5} \mathrm{~V}$ vzhodnoslovanski redakciji cerkvene slovanščine prihaja do mešanja grafemov $\boldsymbol{x}$ in or (3pl praes. *vbvbrgetb > въвьргоүтыь, *vъstbrzajote > въстьрьзающе : *studenьсь > стжаєньць, *otъ оbојu > отъ овоњ (OE)), kar kaže na sovpad odrazov praslovanskih *o in $* u$, medtem ko je (z izjemo v položaju za praslovanskimi trdonebniki) opazno precej dosledno razlikovanje med grafemi $\mathbf{A}$ in a ter $\mathbf{m}$ in г (*vermę > врьмы, *desętaja >

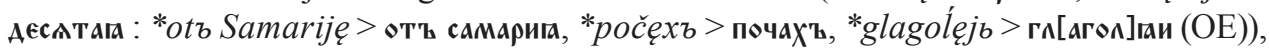


$>$ vsl. *e, tj. ožanje praslovanskega jata kot posledica zgodnjega raznosnjenja praslovanskih nosnikov, ki se je ohranil kot samostojni fonem. ${ }^{6}$

\subsubsection{Starejše samosplošnovzhodnoslovanske glasovne značilnosti}

Starejše glasovne značilnosti, ki so značilne samo (ali predvsem) za vzhodno slovanščino, so:

a) psl. ${ }^{*}$ CorC,${ }^{*}$ ColC, ${ }^{*}$ CerC, ${ }^{*}$ CelC $>$ vsl. CoroC, ColoC, CereC, ColoC/ C'eloC (psl. *gordb 'mesto' > vsl. городъ > rus. го́pod, brus. гópad, ukr. город; psl. *zolto 'zlato' > vsl. зопото > rus. золлото, brus. золлата, ukr. золлото; psl. *bergъ 'breg' > vsl. верегъ > rus. бёрег, brus. бёраг, ukr. бёрег; psl. *melko 'mleko' > vsl. молоко > rus. молоко́, brus. малако́, ukr. молоко́; psl. *'šelmъ 'šlem, čelada' > vsl. шеломъ);

b) psl. ${ }^{*} \boldsymbol{C b r C}:{ }^{*} \boldsymbol{C r b C},{ }^{*} \operatorname{CbrC}:{ }^{*} C r b C,{ }^{*} \boldsymbol{C b l C}:{ }^{*} C l b C,{ }^{*} \boldsymbol{C b l C}:{ }^{*} C l b C>$ vsl.

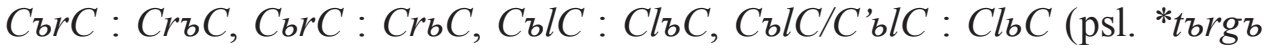
'trg' > vsl. търгъ : psl. Asg *krъvb 'kri' > vsl. кръвь; psl. *vbrxъ 'vrh'> vsl. вьрХ'ъ : psl. *krbstz 'krst, križ'> vsl. крьст'ъ; psl. *dzlgъ 'dolg' > vsl.

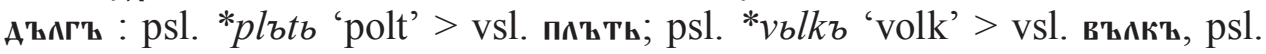
*žbltъjb 'rumen' > vsl. жьлттыи : psl. *slbza 'solza' > vsl. сльза); sporadično pojavljanje oblik z drugim polnoglasjem (rus. второе полногласие) pri medsoglasniških dvoglasniških zvezah polglasnik + jezičnik v krepkem položaju (psl. *vъrvъka > vsl. вьръвъка > rus. верёвка, brus. вяро́ўка, ukr. вірьовкка);

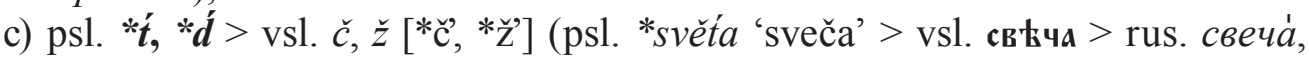
$(\rightarrow$ brus. све́чка), ukr. свічá; psl. *mеd́a 'meja' > vsl. мєжа > rus. межа́, brus. мяжа̀, ukr. межа́); ${ }^{7}$

kar naj bi kazalo na obstoj različnih fonemov $* a$ in $* \ddot{a}$ (v položaju ne za praslovanskimi trdonebniki) (psl. *pasti 'pásti' : Npl *pęsti 'pestí' > vsl. пасти [pasti] : плсти [pästi]) (IGRJ: 64-65, 61). V prid tej domnevi govori tudi glasovna sprememba psl. ${ }^{*} e^{*}{ }^{*} C^{\prime} a>$ vsl. * $\ddot{a}>$ S rus. $e$ (Тер-Аванесова 1995).

${ }^{6}$ To potrjujeta: 1) stanje v nekaterih (tako severnih kot južnih) ruskih narečjih, v katerih se pojavljata fonem /§/ (ozki e, dvoglasnik ię) (rus. е закрытоe) kot odraz psl. *ě in fonem /e/ (srednji e, široki ę, dvoglasnik ei) (rus. е открытоe) kot odraz psl. *e (s katerim je po vokalizaciji praslovanskih polglasnikov v krepkem položaju sovpadel odraz psl. ${ }^{*}$ ) (IGRJ: 62, 80-81, 139-140; RD: 30-31): psl. *ě : *e/*b > vsl. *e : *e (psl. *lěsb, *lěto,

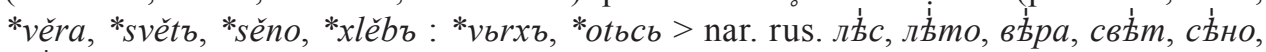
хль́⿱一𫝀 : ве́p $x$, оте́u); 2) stanje v jugozahodni beloruščini in ukrajinščini (kjer je *e pozneje sovpadel z odrazom podaljšanega $* e$ (prim. 2.1)).

${ }^{7}$ Medtem ko se v vzhodnoslovanski redakciji cerkvene slovanščine starocerkvenoslovanski жа pogosto zamenjuje z ж (*osod́ajemyję > осжжакмыг (1076)), se starocerkvenoslovanski шт veliko redkeje s ч (*boga sę bojęte > в[ог]а са вогаче (1095)) (IGRJ: 68), toda ne še v OE. 
č) psl. *(j)e-> jsl., zsl. *(j)e- : vsl. o- (psl. *(j)ezero ‘jezero’ > jsl., zsl. *(j)ezero : vsl. *оzеro > stcsl. єзеро : vsl. өзеро > rus. озеро, brus. во́зера, ukr. озеро);

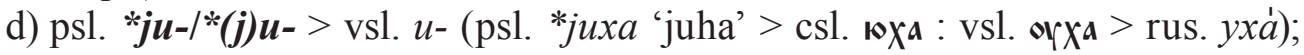

e) psl. *gn > vsl. $n$ v tipu psl. *dvignoti > vsl. двимоүти > rus. двйнуть (: psl. *gnе̌zdo > vsl. гnłзао > rus. гнездо́, brus. гняздо́, ukr. гніздо́).

\subsection{Starejše nesplošnovzhodnoslovanske glasovne značilnosti}

Starejše nesplošnovzhodnoslovanske glasovne značilnosti so nastale v predzgodovinski dobi, nekatere od njih dele vzhodne slovanščine povezujejo z ostalimi slovanskimi makrogeolekti. ${ }^{8}$

Praslovanski $* k^{E 2},{ }^{E 2}, * x^{E 2}$ so se na večjem delu slovanskega jezikovnega ozemlja po praslovanski mlajši regresivni (drugi) palatalizaciji spremenili v ${ }^{*} c^{E 2}, *_{3}{ }^{E 2},{ }^{*}{ }^{E 2} .{ }^{9}$ Odsotnost palatalizacije omenjenih glasovnih zaporedij izkazuje novgorodsko-pskovska vzhodna slovanščina (zahodna osrednja ruščina), in sicer že v najstarejših zapisih na brezovem lubju iz 11. stoletja, v posameznih leksemih pa jo potrjuje tudi stanje $\mathrm{v}$ nekaterih sodobnih severozahodnoruskih govorih: psl. $*^{E 2},{ }^{*} g^{E 2}, * x^{E 2}>$ vsl. $c^{E 2}, 3^{E 2}, s^{E 2}$ : novg.-psk. vsl. $k^{E 2}, g^{E 2}, x^{E 2}$ (psl.

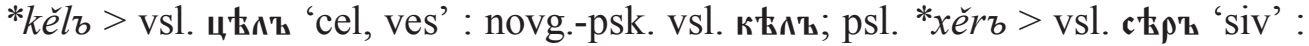
psl. *xěrb > novg.-psk. vsl. $\chi \mathbf{k} \rho \mathbf{b}$ 'sivina; sivo (neokrašeno) sukno'; psl. *kbrky> vsl. цьркы 'cerkev' : novg.-psk. vsl. кьркт) (Зализняк 2004: 41-45; RD: 62). ${ }^{10}$

Praslovanska ${ }^{*} \boldsymbol{s} \boldsymbol{k}^{E 2},{ }^{*} \boldsymbol{z} \boldsymbol{g}^{E 2}$ sta se v vzhodni slovanščini z izjemo v novgorodsko-pskovski vzhodni slovanščini (v kateri sta podobno kot zaporedja $* k^{E 2}$, ${ }^{*} g{ }^{E 2},{ }^{E} x^{E 2}$ ostala nespremenjena) najverjetneje podobno kot $\mathrm{v}$ južni slovanščini po praslovanski mlajši regresivni (drugi) palatalizaciji spremenila $\mathrm{v}{ }_{s c}, *_{z z}$ :

${ }^{8}$ Pri določanju arealov glasovnih značilnosti so zgolj zaradi lažje orientacije v oklepaju navedena tudi poimenovanja s stališča mlajših vzhodnoslovanskih geolektov hierarhične stopnje jezika (npr. zahodna osrednja ruščina, jugozahodna beloruščina, severna ukrajinščina), ki za tu obravnavano obdobje seveda niso upravičena.

${ }^{9}$ Simbol ${ }^{*} E_{2}$ označuje praslovanska sprednja samoglasnika, ki sta povzročala praslovansko mlajšo regresivno (drugo) palatalizacijo (psl. ${ }^{*} \check{e}_{2},{ }^{*}{ }_{-} i_{2}$ ), simbol ${ }^{*} E_{3}$ pa praslovanske sprednje samoglasnike, ki so povzročali praslovansko progresivno (tretjo) palatalizacijo (psl. $*_{i},{ }^{*},{ }^{*}{ }_{e}$ ).

${ }^{10} \mathrm{~V}$ stari novgorosko-pskovski ruščini in nekaterih sodobnih severozahodnih ruskih narečjih se pojavljajo tudi zaporedja ${ }^{E 3} g,{ }^{E 3} x$, ki bi kazala na izostanek delovanja praslovanske progresivne (tretje) palatalizacije (psl. ${ }^{*} v_{b} \times 0>$ vsl. вьсє : Novgorod, Pskov въх $\mathbf{\bullet}$; psl. *ne lbgě (tj. Dsg od psl. *loga z istim korenom kot v psl. *lbgъkъ 'lahek') (> stcsl. ме льзы) $\rightarrow$ vsl. мельзга, мельза, rus. нельзя : Novgorod, Pskov мельга, nar. rus. нельга, kar pa se navadno pojasnjuje kot drugotno (Фасмер 1971: 61; Зализняк 2004: 41-45; RD: 62). Oblike tipa Novgorod, Pskov въxo izkazujejo zelo zgodnjo spremembo korenskega polglasnika po zlogovni harmoniji psl. ${ }^{*}{ }_{b} C O>{ }^{*} b C O$ (psl. ${ }^{*} d b s k a>{ }^{*} d b s k a$ 'deska' $>$ vsl. Ałcka), po kateri je povzročitelj progresivne palatalizacije izginil. V oblikah tipa Novgorod, Pskov мепьга je lahko prišlo do izravnave po nepalataliziranih oblikah tipa psl. *loga. 
psl. ${ }^{*} k^{E 2}, *_{z g}{ }^{E 2}>$ vsl. ${ }^{*} s c, *_{z z}>$ st, $z d$ (psl. *dbska, *mězga $\rightarrow$ vsl. Lsg *na

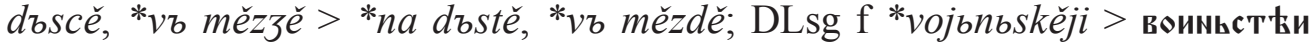
(12. st.), Npl m *zamoŕbskiji > заморьстии (1282)) (IGRJ: 92). Tovrstnih odrazov že v najstarejših pisnih spomenikih poleg novgorodsko-pskovske vzhodne slovanščine ne izkazujeta še dva stara vzhodnoslovanska geolekta, kar pa se navadno pojasnjuje kot drugotno stanje, povezano z drugimi soglasniškimi arhaizmi in inovacijami na teh območjih: 1) pološko-smolenska vzhodna slovanščina (severovzhodna beloruščina) ima odraze tipa $\breve{s} \check{c}$, *ž̌̆ (or Витевьце 'v Vitebsku', or Gmonenьщє 'v Smolensku' (1399)), kar je najverjetneje odraz cokanja/čokanja (IGRJ: 92; Shevelov 1964: 299); 2) poleško-kijevska vzhodna slovanščina (jugozahodna beloruščina in severna ukrajinščina) izkazujeta odraze tipa sk, zg (*po dbskě > по аъск' (11. st.), *skěpišče > скћпищє, въ [...] Пимьск' 'v Pinsku', въ роүсьск' земли 'v ruski deželi', Gмолимьск' 'v Smolensku', въ роүсьскњи сторон' вєлиц'и 'v veliki ruski deželi'; *skěpъka > rus. ске́пка, ukr. скіпка), kar pa je verjetno nastalo znotraj drugotnega razvoja tipa psl. * $s k^{E 2}>$ vsl. ${ }^{*} s c$ '> ${ }^{*} s t^{\prime}>s k$ ' (IGRJ: 92-93; Shevelov 1964: 297-300) in je verjetno povezano z izostankom delovanja praslovanske mlajše regresivne

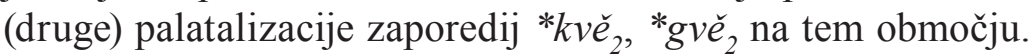

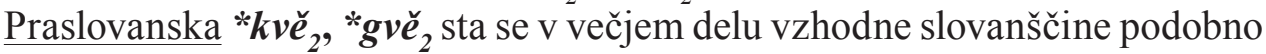
kot v južni slovanščini po praslovanski mlajši regresivni (drugi) palatalizaciji palatalizirala $\mathrm{v}{ }^{*} \mathrm{cve}_{2},{ }^{*}{ }_{3} v \check{e}_{2}$, medtem ko je v novgorodsko-pskovski in poleško-kijevski vzhodni slovanščini podobno kot v zahodni slovanščini palatalizacija najverjetneje izostala: psl. *kvě $\check{e}_{2} *_{g v \check{e}_{2}}>$ vsl. $c v \check{e}_{2}, *_{3} v \check{e}_{2}>z v \check{e}_{2}$ : poleš.-kij. vsl. *kvě ${ }_{2}$, 'gvě ${ }_{2}$ (psl. *květr 'cvet' > vsl. цвњтъ > rus. u̧вèm, SV brus. = knj.

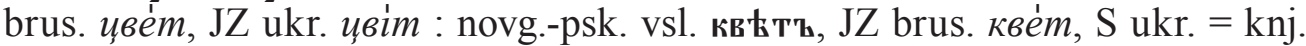

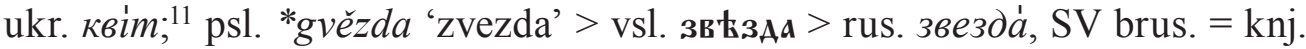
brus. звязда́, ukr. звізда́ : novg.-psk. vsl. гвњзаa; ${ }^{12}$ psl. *o(b)gvězditi > JZ brus. (Brjansk) агвяздзіиь 'udariti') (Shevelov 1964: 301; Зализняк 2004: 45; GGBM: 74-75; Wexler 1977: 93).

Praslovanska $* \boldsymbol{t} \boldsymbol{l}, * \boldsymbol{d} \boldsymbol{l}$ sta se v večjem delu vzhodne slovanščine poenostavila $\mathrm{v} l \mathrm{z}$ izjemo ozemlja pskovske in deloma novgorodske vzhodne slovanščine, kjer sta prešla v $k l, g l$ : psl. *tl, *dl> vsl. $l$ : psk.-novg. vsl. $(k) l$, $(g) l$. Soglasniška sklopa $k l, g l$ sta dobro dokumentirana v starem pskovskem narečju (*sosrětli $>$ соүстрћкли, *privedli > привегли (14. st.)), v sodobnem pskovskem narečju pa se pojavljajo le še njuni ostanki (*pričbtla sę> прицкла́cь, *vedli > веглй) (IGRJ: 94-95), medtem ko ima staro novgorodsko narečje tako $l$ kot $k l, g l$ (*orz-vedli > розвьли $=$ rozveli (14. st.) : *po-vedli > повеглt $=$ povegli) (Зализняк 2004: 49).

Praslovanska $* \grave{\boldsymbol{o}}$, *ö sta se v severovzhodni in novgorodsko-pskovski vzhodni slovanščini (tj. v celotni ruščini) najverjetneje prvotno odražala kot različna fonema, kar potrjuje stanje v nekaterih (tako severnih kot južnih) ruskih narečjih, v katerih se pojavljata fonem / $/$ (ozki $o$, dvoglasnik uo) (rus. о закрытое) kot

${ }^{11}$ Nepalatalizirane oblike tipa brus. кве́m, ukr. квim se razlagajo tudi kot posledica poznejšega prevzema iz poljščine (IGRJ: 69; GGBM: 74-75) ali kot nejasne (IGUM: 103).

12 Oblika ukr. звіздá je lahko tudi prevzeta iz cerkvene slovanščine (Shevelov 1964: 301). 
odraz psl. *ò in fonem /o/ (srednji $o$, široki $o$, dvoglasnik ou) (rus. о открытое) kot odraz psl. *ö (s katerim je po vokalizaciji praslovanskih polglasnikov v krepkem položaju sovpadel odraz praslovanskega *̋) (IGRJ: 62, 80-81, 139-140;

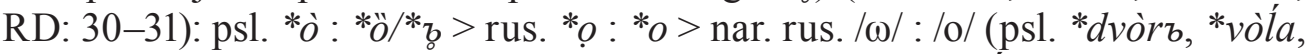
*naròdb, *mъnògo, *sedló, *körva, *óldъka : *gödz, *pöle, *zôlto, *sünъ >

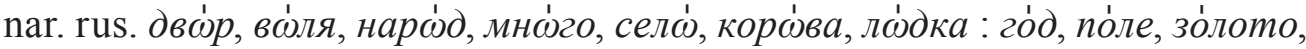
сон). Razlikovanje med različnima ojevskima fonemoma izvira iz obdobja, v katerem so v vzhodni slovanščini tonemska nasprotja še obstajala, pojav pa je dokumentiran zelo pozno v zgodovinski dobi (ruski ozki $o$ se je označeval s posebnim znakom nad samoglasnikom, to je t. i. камора): *uròdb $>\operatorname{orp} \hat{\mathbf{8}} \mathbf{A} \mathbf{z}$,

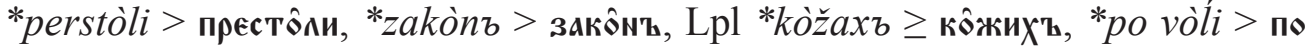
воิи̂и : *pöjasъ > по́raç (16. st.) (Васильев 1929).

Vzhodnoslovanski $\breve{c}, \breve{z}, \check{s}$ in $\boldsymbol{c}, \boldsymbol{z}, \boldsymbol{s}$ ponekod v vzhodni slovanščini najverjetneje pod vplivom baltskofinskih uralskih jezikov kažejo težnjo po sovpadu, pri čemer je areal sovpada zlitnikov $\check{c}, c$ neprimerno večji od areala sovpada pripornikov $\check{z}, z$ in $\check{s}, s$. Vzhodnoslovanska $\check{c}, c$ sta sovpadla ponekod v (severni in osrednji) severovzhodni in novgorodsko-pskovski vzhodni slovanščini (v severni in osrednji ruščini) ter $\mathrm{v}$ pološko-smolenski vzhodni slovanščini (v severovzhodni beloruščini), in sicer v $c$-jevski glas (pojav se imenuje cokanje) ali $\check{c}$-jevski glas (pojav se imenuje čokanje) (IGRJ 84-88; RD 67-70; BD: 57, 205): psl. ${ }^{*} \check{c} / *^{*} t,{ }^{*} c /{ }^{*} k\left(v \check{e}_{2}\right)>$ vsl. ${ }^{*} \check{c}:{ }^{*} c>$ rus., SV brus. ${ }^{*} c>c / \check{c}$. Sovpad $\check{c}, c$ je izpričan od 11. stoletja: Novgorod: *pěvbcb> пҺвьчь, *květb> чв ттъ : *červo > цркво (1095), *с̌ьto > цьтө (po 1192); Pskov, Polock, Smolensk: Dpl *kupьcemъ $>$ когпчемъ (1229), *konьčany > көмцаны (1383), *starbcь > старечь (15. st.). Sovpad vzhodnoslovanskih $\check{z}, z$ in $\check{s}, s$ pa je znan samo v starem pskovskem narečju (Горшкова 1972: 68-69): psl. *̌̌z/*d, $*_{z}>$ vsl. $*_{z}: *_{z}>$ Pskov $*_{z}$; psl. $*_{s}, *_{s}>$ vsl. $*_{s}: *_{s}>$ Pskov $*_{s}$. Cokanje/čokanje je bilo v preteklosti veliko bolj razširjeno, pod vplivom govorov, ki ga ne poznajo, se namreč opušča. ${ }^{13}$

\subsection{Starejši vzhodnoslovanski geolekti}

Od starejših nesplošnovzhodnoslovanskih glasovnih značilnosti so se nekatere pojavljale na manjših območjih (vsl. $*_{z ̌} / *_{z}, *_{s} / *_{s}>$ Pskov $\left.*_{z}, *_{s}\right)$ oziroma na nestrnjenem ozemlju (vsl. $\left.{ }^{*} c /{ }^{*} c>{ }^{*} c\right)$, medtem ko nekatere od njih zajemajo precej večje areale $\left(\right.$ psl. $*_{k}^{E 2}, *^{*}{ }^{E 2}, *^{E 2}>*_{k}, *_{g}, *_{x}: *_{c}, *_{3}, *_{s} ;$ psl. $*_{s k} k^{E 2}$,

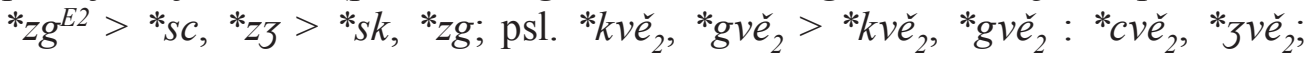

${ }^{13}$ Podobno težnjo po sovpadu praslovanskih sičnikov in šumevcev znotraj slovanskega jezikovnega sveta poznajo tudi nekateri drugi geolekti, ki so (bili) v zelo intenzivnem stiku z nemščino. Sovpad zlitnikov psl. ${ }^{*} \check{c} / *_{c}>{ }^{*} c$ pozna dolnja lužiščina, medtem ko je sovpad zlitnikov in pripornikov psl. ${ }^{*} \check{c} / *^{*}, *_{z} / *_{z}, *_{s} / *_{S}>*_{c} c,{ }_{z}, *_{s}$ značilen za malopoljska, nekatera mazovijska in nekatera šlezijska narečja poljščine (t. i. mazurzenie) (Dejna 1981: 23, 33, 39), polabščino ter baško podnarečje (tolminskega narečja) slovenščine (t. i. slekanje) (Šekli 2013b: 108). 
psl. $*_{t l}, *^{*} l l>$ Pskov, deloma Novgorod $* k l,{ }^{*} g l$; psl. $*^{*}: *^{*}>*_{o}: *_{o}$ ). Znotraj vzhodne slovanščine se je torej že zelo zgodaj izoblikovalo vsaj pet osnovnih starejših vzhodnoslovanskih geolektov z naslednjimi definicijskimi lastnostmi: 1) severovzhodna vzhodna slovanščina (ruščina brez zahodne osrednje ruščine): psl. $*^{E 2}, *^{E 2}, * x^{E 2}>\mathrm{SV}$ vsl. ${ }^{*} c, *_{3}, *_{s}$; psl. $*_{s k} k^{E 2}, *_{z g} g^{E 2}>\mathrm{SV}$ vsl. ${ }_{s c}, *_{z}$; psl. *kvě ${ }_{2},{ }^{*} g v \check{e}_{2}>\mathrm{SV}$ vsl. ${ }^{*} c v \check{e}_{2}, *_{3} v \check{e}_{2}$; psl. *tl, *dl>SV vsl. *l; vsl. *č : $*_{c}>\mathrm{SV}$ vsl. ${ }^{*} c$; psl. $*^{*}: *^{*}>\mathrm{SV}$ vsl. ${ }^{*} 0: *_{o}$;

2) novgorodsko-pskovska vzhodna slovanščina (zahodna osrednja ruščina), imenovana po krajih Novgorod (rus. Новгород) in Pskov (rus. Псков): psl. $*_{k}^{E 2}, *^{E 2}, *_{x}^{E 2}>$ novg.-psk. vsl. $*_{k}, *_{g},{ }^{*} x$; psl. $*_{s} k^{E 2}, *_{z} g^{E 2}>$ novg.-psk. vsl. *sk, *zg; psl. *kvě ${ }_{2}, *^{\prime} v \check{e}_{2}>$ novg.-psk. vsl. *kvě ${ }_{2}, *^{\prime} v \check{e}_{2} ;$ psl. *tl, *dl $>$ novg.-psk. vsl. ${ }^{*}(k) l,{ }^{*}(g) l$; vsl. $*_{c}$ : $*_{c}>$ novg.-psk. vsl. ${ }^{*} c$; psl. ${ }^{*} \dot{o}: *_{o ̈}>$ novg.-psk. vsl. ${ }^{*} O: *_{O}$; notranje se je delila na novgorodsko (vsl. $*_{z} / *_{z}, *_{S} / *_{S}$ $>$ Novgorod $* \check{z} / *_{z}, *_{S} / *_{s}$; psl. *tl, *dl> Novgorod $\left.*(k) l, *(g) l\right)$ in pskovsko $\left(\right.$ vsl. $*_{z} / *_{z}, *_{s} / *_{s}>$ Pskov $*_{z}, *_{s} ;$ psl. $*_{t l}, * d l>$ Pskov $* k l, *_{g l}$ ) narečje;

3) pološko-smolenska vzhodna slovanščina (severovzhodna beloruščina), imenovana po krajih Polock (brus. Полацк, rus. Полоцк) in Smolensk (brus. Смаленск, rus. Смоленск): psl. ${ }^{*} k^{E 2},{ }^{*} g^{E 2}, *^{E 2}>$ pološ.-smol. vsl. ${ }^{*} c,{ }^{*},{ }^{*}$;

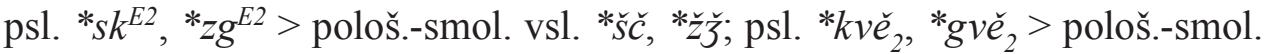
vsl. *cvě ${ }_{2},{ }^{*}{ }_{3} v \check{e}_{2}$; psl. ${ }^{*} t l,{ }^{*} d l>$ pološ.-smol. vsl. *l; vsl. ${ }^{*}{ }^{*}:{ }^{*} c>$ pološ.-smol. vsl. ${ }^{*} c$; psl. ${ }^{*} \dot{o}: *^{*}>$ pološ.-smol. vsl. ${ }^{*} o$;

4) poleško-kijevska vzhodna slovanščina (jugozahodna beloruščina in severna ukrajinščina), imenovana po pokrajini Polesje (brus. Палессе, ukr. Полісся) in kraju Kijev (ukr. Київ): psl. $*^{* 2},{ }^{*} g^{E 2}, *^{E 2}>$ poleš.-kij. vsl. ${ }^{*} c, *_{3}, *_{s}$;

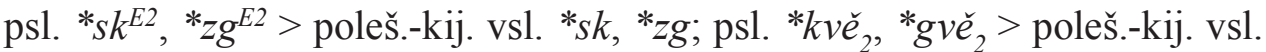

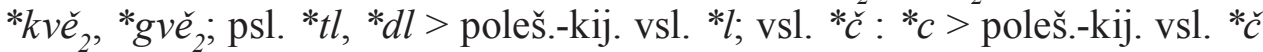
: *c; psl. ${ }^{*} \dot{o}: * \ddot{o}>$ poleš.-kij. vsl. ${ }^{*}$;

5) jugozahodna vzhodna slovanščina (južna ukrajinščina): psl. $* k^{E 2}, *^{E}{ }^{E 2}, * x^{E 2}$ $>\mathrm{JZ}$ vsl. $*_{c}, *_{3}, *_{s}$; psl. * $*^{E 2}, *_{z g}{ }^{E 2}>\mathrm{JZ}$ vsl. $*_{s c}, *_{z 3}$; psl. *kvě ${ }_{2}, *_{g v \check{e}_{2}>}$ $\mathrm{JZ}$ vsl. ${ }^{*} c v \check{e}_{2}, *_{3} v \check{e}_{2}$; psl. ${ }^{*} t l,{ }^{*} d l>\mathrm{JZ}$ vsl. ${ }^{*} l$; vsl. ${ }^{*} \check{c}: *_{c}>\mathrm{JZ}$ vsl. ${ }^{*} c \check{c}:{ }^{*}$; psl. ${ }^{*} \dot{o}: * \ddot{o}>\mathrm{JZ}$ vsl. ${ }^{*} o{ }^{14}$

${ }^{14} \mathrm{Tu}$ predlagana delitev starih vzhodnoslovanskih geolektov ne sledi nobeni doslej predlaganih (Šahmatov, Durnovo, Lehr-Spławiński, Trubetzkoy, Shevelov, povzeto v Wexler 1974: 75-76; Gorškova). Kratek komentar zadnjih dveh delitev: 1) zgodovinskoglasoslovna delitev na osnovi starejših glasovnih značilnosti (novgorodsko-suzdaljsko, pološko-rjazanjsko, kijevsko-poleško, galicijsko-podoljsko narečje) (Shevelov 1964: 297-301, 386, 469-470) je problematična predvsem zaradi definicije pološko-rjazanjskega narečja na osnovi predpostavke, da je (popolno) akanje arhaizem (bolj primerna se zdi poznejša Shevelovova izločitev pološko-smolenskega narečje); 2) zgodovinskonarečjeslovna delitev (Novgorod, Pskov = severozahod; Rostov, Suzdalj = severovzhod; Rjazanj, Černigov = jugovzhod; Polock, Smolensk = zahod; Galicija in Volinija, Kijev = jugozahod (Горшкова 1972: 64-71)) ne upošteva nekaterih starejših (odrazi psl. * $k^{E 2}$, $\left.*_{g}^{E 2}, *^{E 2} ; *_{s k^{E 2}}, *_{z} g^{E 2} ; *_{k v \check{e}_{2}}, *_{g v} \check{e}_{2} ; * \grave{o}: * \ddot{o}\right)$, vključuje pa nekatere mlajše glasovne značilnosti (odrazi psl. $* v, * g$ ) ter narečja postavlja v čas ok. 1100. 


\begin{tabular}{|c|c|c|c|c|c|}
\hline Psl. & SV vsl. & $\begin{array}{c}\text { novg.-psk. } \\
\text { vsl. }\end{array}$ & $\begin{array}{c}\text { pološ.-smol. } \\
\text { vsl. }\end{array}$ & $\begin{array}{c}\text { poleš.-kij. } \\
\text { vsl. }\end{array}$ & JZ vsl. \\
\hline${ }^{*} \mathbf{k}^{\mathrm{E} 2},{ }^{*} \mathrm{~g}^{\mathrm{E} 2},{ }^{*} \mathbf{x}^{\mathrm{E} 2}$ & $*_{\mathrm{c},} *_{3}, *_{\mathrm{s}}$ & ${ }^{*} \mathrm{k},{ }^{*} \mathrm{~g},{ }^{*} \mathbf{x}$ & $*_{\mathrm{c}}, *_{3}, *_{\mathrm{s}}$ & $*_{\mathrm{c}}, *_{3}, *_{\mathrm{s}}$ & $*_{\mathrm{c}}, *_{3}, *_{\mathrm{s}}$ \\
\hline${ }^{*} \mathrm{sk}^{\mathrm{E2}}$ & $*_{\mathrm{sc}}$ & *sk & *气̌́ & *sk & $*_{\mathrm{Sc}}$ \\
\hline${ }^{*} \mathrm{Zg}^{\mathrm{E} 2}$ & $*_{\mathrm{z} 3}$ & $*_{z g}$ & $*{ }_{z} \mathbf{z}$ & ${ }^{*} \mathrm{zg}$ & $*_{\mathrm{Z} 3}$ \\
\hline *kvě & $*_{\text {cvě }}$ & *kvě & $*_{\text {cvě }}$ & *kvě & $*_{\text {cvě }}$ \\
\hline *gvě & 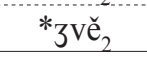 & ${ }^{*}$ gvě & $*_{3} \mathrm{zer}_{2}$ & ${ }^{*}$ gvě & 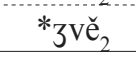 \\
\hline$*$ tl, *dl & $* 1$ & *(k)l, *(g)l & $* 1$ & $* 1$ & $* 1$ \\
\hline$* \check{\mathbf{c}}: * \mathbf{c}$ & $*$ & *ç & *c & $*_{\mathrm{c}}: *_{\mathrm{c}}$ & $*_{\mathrm{c}}: *_{\mathrm{c}}$ \\
\hline *ò & *0 & *0 & $*_{0}$ & $*_{0}$ & $*_{0}$ \\
\hline *ö & $*_{0}$ & $*_{0}$ & $*_{0}$ & $*_{0}$ & $*_{0}$ \\
\hline
\end{tabular}

Starejši vzhodnoslovanski geolekti in njihove razlikovalne glasovne značilnosti.

Kljub relativno zgodnjim zametkom več vzhodnoslovanskih geolektov pa je potrebno pripomniti, da imajo nekatere starejše glasovne značilnosti, ki služijo kot genetsko merilo za njihovo definiranje, v nadaljnjem spreminjanju le-teh manjši pomen: odrazi psl. $*^{E}{ }^{E 2},{ }^{*} g^{E 2}, * x^{E 2} ; *_{s} k^{E 2}, *^{*} g^{E 2}$ so bili zaradi izravnav znotraj pregibalnih vzorcev po večini odpravljeni, podobno se je dogajalo $\mathrm{s}$ soglasniškima sklopoma $* k l$, $* g l$, sovpad $*_{c}, *_{c}$ ni bil prisoten na celotnem arealu in je bil kasneje ponekod odpravljen, različna odraza psl. *ò : *ö sta se ohranila samo v nekaterih govorih. Vzhodnoslovanski jezikovni prostor se je v skupen areal povezal pozneje v okviru mlajših splošnovzhodnoslovanskih inovacij, dejansko oblikovanje posameznih vzhodnoslovanskih jezikov pa se je pričelo v okviru mlajših nesplošnovzhodnoslovanskih inovacij.

Zložniška sistema kasnejše severovzhodne vzhodne slovanščine (ruščine) in kasnejše jugozahodne in zahodne vzhodne slovanščine (ukrajinščine in beloruščine) sta se po starejših splošno- in nesplošnovzhodnoslovanskih glasovnih spremembah razlikovala $\mathrm{v}$ prisotnosti/odsotnosti fonema $o$ :

a) severovzhodna vzhodna slovanščina (ruščina):

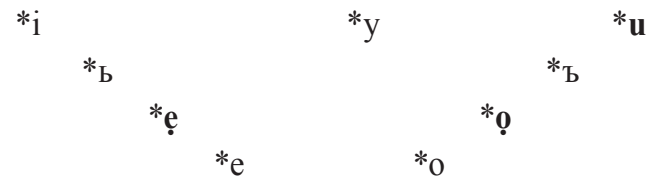

$(* a ̈) * a$

b) jugozahodna in zahodna vzhodna slovanščina (ukrajinščina in beloruščina):

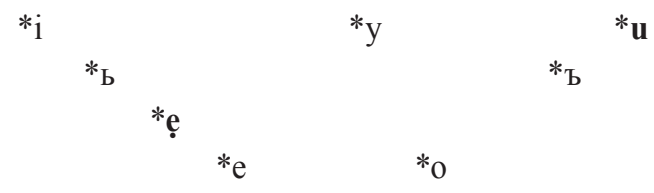

(*ä) *a 


\subsection{Mlajše splošnovzhodnoslovanske glasovne značilnosti}

Divergentno izhodišče vzhodne slovanščine (severovzhodna : novgorodsko-pskovska : pološko-smolenska : poleško-kijevska : jugozahodna vzhodna slovanščina) je doživelo konvergentno spreminjanje v okviru mlajših splošnovzhodnoslovanskih glasovnih inovacij, ki so vzhodnoslovanski jezikovni prostor za nekaj časa povezale $\mathrm{v}$ relativno enoten geolekt. Le-te so povezane $\mathrm{z}$ odrazi praslovanskih polglasnikov $*_{b},{ }^{*}$, in sicer $\mathrm{z}$ njihovo onemitvijo $\mathrm{v}$ šibkem položaju v 11. stoletju ter njihovo vokalizacijo v polne samoglasnike v krepkem položaju $\mathrm{v}$ istem času ali nekoliko pozneje:

a) psl. ${ }^{*} \boldsymbol{b},{ }^{*} \boldsymbol{b}>$ vsl. $\varnothing\left(\right.$ psl. ${ }^{*}$ sъpati $>$ vsl. съпати $>$ rus. cnámb, brus. cnáub, ukr. cnámu), izpričano od 2. polovice 11. stoletja: *kъnęь > кмазь (1068),

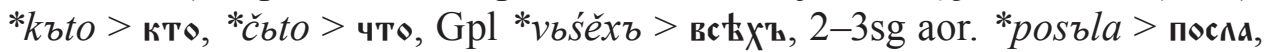
*prizъvavъ > призвавъ, 3sg praes. *umbretь > оүмреть (ok. 1100);

b) nastanek mehkostne korelacije, tj. fonologizacija prej alofonskega razmerja nemehčani : mehčani soglasnik v soglasniškem sistemu, zaradi onemitve praslovanskih polglasnikov v šibkem položaju: psl. ${ }^{*} \boldsymbol{C}^{\boldsymbol{O}}:{ }^{*} \boldsymbol{C}^{\boldsymbol{E}}>$ vsl. ${ }^{*} C$ : ${ }^{*} C^{\prime}$ (psl. ptc. praet. pass. ${ }^{*}$ danъ $>$ rus. dáн [dàn] 'dan' : psl. ${ }^{*}$ danb $>$ rus. да́нь [dàn'] 'davek, tribut');

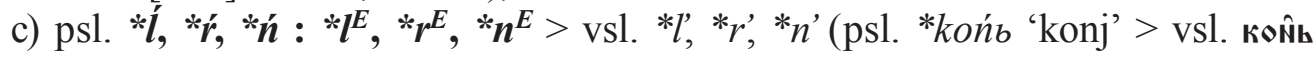
$>$ rus. ко่нь [kón'], brus. коंнь [kón'], ukr. кінь [k'in']; psl. *nitb 'nit' > rus.

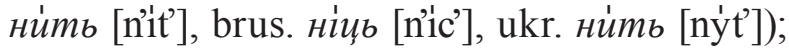

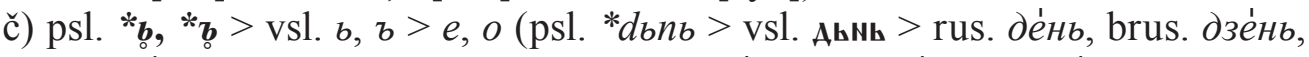

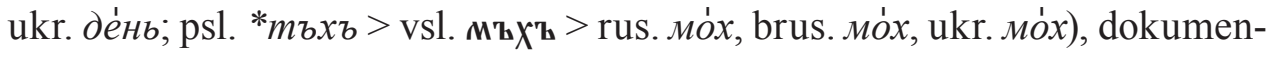
tirano od 2. polovice 12. stoletja: *studenвсь > стоүаєеєц, Lpl *sbnbmiščixb $>$ сомьмицихъ (1164), *čbto bylo nemirbno > что въаль мемирно, Dsg m/n *latinbskujeти $\geq$ патимескомоу, *dobrъjь > Аъврии, *mirb > миро (1229);

d) psl. ${ }^{*} \boldsymbol{C a r C},{ }^{*} \boldsymbol{C b l C},{ }^{*} \boldsymbol{C b r} C,{ }^{*} \boldsymbol{C b l C}>$ vsl. CorC, ColC, CerC, ColC/C'elC (psl. *tъrgъ 'trg' > vsl. търгъ > rus. mópz, brus. móp, ukr. mópz; psl. *dъlgъ 'dolg' > vsl. а'илгъ > rus. доллг, brus. до́уг, ukr. довв; psl. *vьrхъ 'vrh' > vsl. вьрХ'ъ > rus. ве́рx, brus. ве́рx, ukr. ве́рx; psl. *vblkъ 'volk' > vsl. в'ълкъ > rus. воллк, brus. во́ўк, ukr. вовк; psl. *žьltъjь 'rumen' > vsl. жьлт'ыи > rus. жёлтылй, brus. жо́ўты, ukr. жо́втий), izpričano od 2. polovice 12. stoletja: *pbrsta > перьста (1164), Npl m *mbrtviji > мерьтвии, *tvbrditi > твераити (1229), *za vъlхоуъть > за волхөвомь (1192-1230);

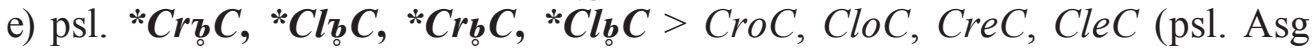
*krъvb 'kri' > vsl. кръвь > rus. кро́вь, brus. кро́ў, ukr. кро́в; psl. *plъtь 'polt' > vsl. ппъть > rus. пло́mь, brus. пло́и̧ь; psl. *krbstъ 'krst, križ' > vsl. крьстъ). 


\section{Oblikovanje vzhodnoslovanskih jezikov}

\subsection{Mlajše nesplošnovzhodnoslovanske glasovne značilnosti}

Mlajše nesplošnovzhodnoslovanske glasovne značilnosti, ki so se pojavile v obdobju 12.-13. stoletja (nekatere od njih torej vzporedno z nekaterimi mlajšimi splošnovzhodnoslovanskimi), so dokončno izoblikovale tri vzhodnoslovanske geolekte in posledično predstavljajo genetska merila v klasifikaciji vzhodne slovanščine na jezike.

Praslovanska $*_{\boldsymbol{e}} \boldsymbol{C}_{\boldsymbol{b}} / \mathbf{b}, \boldsymbol{*}_{\boldsymbol{o}} \boldsymbol{C}_{\boldsymbol{b}} / \mathbf{b}, \mathrm{tj} . \mathrm{psl} . *_{e}, *_{o} \mathrm{v}$ zlogu pred praslovanskim polglasnikom $v$ šibkem položaju, sta se po onemitvi slednjega $\mathrm{v}$ jugozahodni beloruščini in ukrajinščini po nadomestni podaljšavi podaljšala in zožila $\mathrm{v} * \bar{e}$, *ō (tako podaljšani psl. *e je sovpadel z odrazom psl. *̌e, tj. t. i. »novi ě« (ukr. новий Ђ)), medtem ko severovzhodna beloruščina in ruščina sledi kolikostnih sprememb ne izkazujeta (IGRJ: 125-126; GGBM: 88; BD: 32-37, 202; IGUM: 135-136, 152-164; Кальнынь 2000а: 29): psl. *eCb/ъ, ${ }^{*}{ }_{o} C_{b} / \mathfrak{b}>$ JZ brus., ukr.

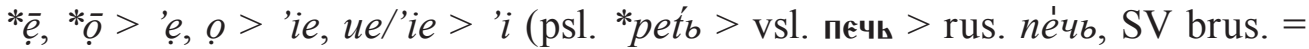
knj. brus. nèu, JZ brus. nêч, nіеч, ukr. niчb; psl. *solb $>$ vsl. сопь $>$ rus. солль, SV brus. = knj. brus. солль, JZ brus. соль, суоль, ukr. сіль)..$^{15}$ Prvi primeri podaljšave sredinskih samoglasnikov se pojavljajo v 2. polovici 12. stoletja: Asg *kamenь > камtки, *učiteĺb > оүчитьль (1164), *ovbca > воовца (1266).

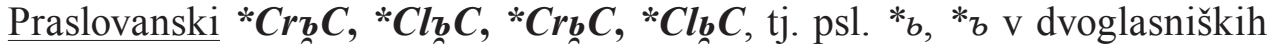
zvezah jezičnik + polglasnik v položaju med soglasnikoma v šibkem položaju, sta se $\mathrm{v}$ ruščini podobno kot $\mathrm{v}$ ostalih položajih spremenila $\mathrm{v} * e,{ }^{*} o$, v beloruščini in ukrajinščini pa $\mathrm{v} * i, * y$ (IGRJ: 106-109; GGBM: 88-90; IGUM: 128-130; Кальнынь 2000b: 36): psl. ${ }^{*} \mathrm{Crb} C,{ }^{*} \mathrm{Cl} b \mathrm{~b},{ }^{*} \mathrm{Crb} C,{ }^{*} \mathrm{Cl} b \mathrm{C}>$ rus.

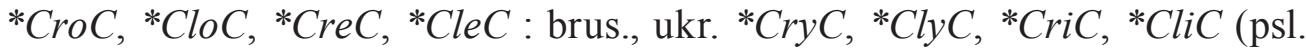

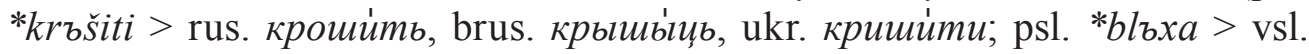
вльха > rus. блоха́, brus. бльхха́, ukr. блиха́; psl. *grьтёti > vsl. грьмьти > rus. греметть, brus. грыме́uь, ukr. гриміти; psl. *blbstěti > vsl. вльстьти > rus. блестеть, brus. блісиець). Prvi zapisi tovrstnih refleksov se pojavljajo v

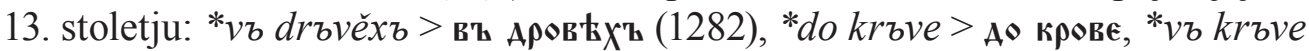
$>$ въ крови, *ustrbmi sę> оүстреми са, *(j)ablbko > гавлоко, *slbzy> спєзы (1296), *krbvi > крови (13. st.) : 3sg praes. *krbnetb > кримєть (1229), *(j)ablъko $>$ гавлыкө (13. st.), 3pl imperf. *drъžaaxq > Аръжахөу (14. st.).

Praslovanska ${ }^{*} \boldsymbol{j} \boldsymbol{j},{ }^{*} \boldsymbol{b} \boldsymbol{j}$, tj. psl. polglasnika v krepkem položaju ${ }^{*}{ }_{b}, *_{b}$ pred *j sta se v ruščini podobno kot v drugih položajih spremenila $\mathrm{v}{ }^{*} e,{ }^{*}, \mathrm{v}$ beloruščini in ukrajinščini pa $\mathrm{v} * i, *^{*}$ (IGRJ: 101-105; GGBM: 104-106; IGUM: 130-132; Пшеничнова 1995: 21): psl. * ${ }_{b j}$, * ${ }_{o j}>$ rus. ${ }^{*} e j$, *oj, brus., ukr. $*_{i j}$, *yj (psl. *šbja > vsl. шига, шьга > rus. шѐя, brus. шь'я, ukr. шия; psl. *živъjb

${ }^{15} \mathrm{~V}$ tipu psl. * ${ }^{\text {vоrnъ }}>$ vsl. воронъ $>$ rus. ворон, ukr. ворон do nadomestne podaljšave $\mathrm{v}$ jugozahodni beloruščini in ukrajinščini proti pričakovanju ni prišlo, saj je relativnokronološko gledano najprej prišlo do nastanka polnoglasnega odraza in šele nato do onemitve praslovanskega polglasnika v šibkem položaju. 
$>$ vsl. живъи > rus. живо́й, brus. жывь', ukr. живйй). Glasovna sprememba se je najverjetneje zgodila že v času vokalizacije praslovanskih polglasnikov v krepkem položaju, prvi zapisi pa se pojavljajo v 2. polovici 13. stoletja: Gpl *svinbjb > свинеи (1270), Gpl *íudbjb > пюаєи (1317), *velikъjь > великои (1339), *vinopbjbca > вимопёіца (1354).

Sprememba $*^{*}>\boldsymbol{o}$ : Vzhodnoslovanski ${ }^{*}$ (iz psl. $\left.{ }^{*} e,{ }^{*} b\right)$ se je v položaju pred trdim soglasnikom in v izglasju spreminjal v $*_{o}$ : psl. $*^{*} / *_{b} /+\left[*_{-} \mathrm{C}^{\mathrm{O}}, \#\right]>$ vsl. *'e > 'o (psl. *zеlепъjь > vsl. зелекъи > rus. зелёный, brus. зялёны, ukr. зеле́ний; psl. *čelo > vsl. чєло > rus. челó, brus. чалó, ukr. чолó), in sicer na dva načina (IGRJ: 128-133; GGBM: 107-111; IGUM: 144-148): 1) v ruščini in beloruščini v položaju za vsemi vzhodnoslovanskimi mehkimi soglasniki, in sicer v južni (»akajoči«) ruščini in beloruščini samo naglašeni *'e: psl. *e/*b

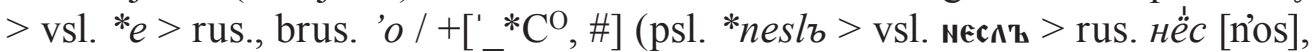
brus. нё́с [n’os], ukr. ніс; psl. *lbnъ > rus. лён [l’on], brus. лён [l’on], ukr. ле́н), v severni (»okajoči «) ruščini tako naglašeni kot nenaglašeni *'e (psl. *neso > $\mathrm{S}$ rus. нёсу' [n'osú], J rus. несý, brus. нясу́, ukr. несý; psl. *pole $>$ vsl. попњ $>\mathrm{S}$ rus. полё [ро́l’o], J rus. полле, brus. поле, ukr. полле); 2) v ukrajinščini naglašeni in nenaglašeni *'e samo v položaju za psl. $*_{s}, *_{z}, *_{c}, *_{\breve{z}}, *_{j}$ : psl. $*_{e} / *_{b}>$ vsl. $*_{e}>$

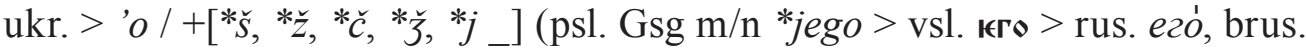
яго, ukr. його́). Prvi primeri spremembe v položaju za sičniki so dokumentirani konec 12. stoletja: 1 pl praes. ${ }^{*}$ sъkažemъ > съкажомъ, *možemъ > моүжоми, *bolženъ > влажонъ (kon. 12. st.); *jьmot́temu > имогчомог (12. st.). V ruščini je do spremembe prihajalo tudi še v času po otrditvi $\breve{s}, \breve{z}>\breve{s}, \check{z}$ (14. st.), v beloruščini ne več (psl. 2sg praes. *jbdeši > vsl. иАєшь > rus. идёшь, brus. iдзёш; psl. *odeda > rus. одёжа, brus. одзе́жа), v ruščini ne več v času otrditve $c$ '> $c$ (2. pol. 15. st.) (psl. *otbcb > vsl. отьць > rus. oméu, brus. ou’éu, ukr. oméų).

Praslovanski $* \boldsymbol{k} \boldsymbol{y}, \boldsymbol{*}^{\boldsymbol{g} y} \boldsymbol{y}, \boldsymbol{x}_{\boldsymbol{y}}$ so se podobno kot $\mathrm{v}$ zahodni slovanščini (z izjemo praslovanskega $* x y$ v poljščini, pomorjanščini in dolnji lužiščini) v večjem delu vzhodne slovanščine palatalizirali v ki, gi, x’i (IGRJ: 127-128; GGBM: 123-124; IGUM: 148-149): ${ }^{16}$ psl. *ky, *gy, *xy > vsl. k’i, g’i, x’i (psl.

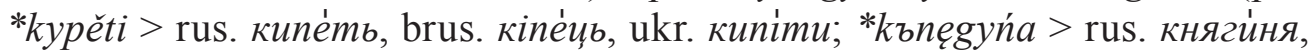
brus. княгіня, ukr. княгиняя; psl. *хуtrъjь > vsl. Х'ытрлыи > rus. хйтрый, brus. ximpbl, ukr. xumpuŭ). Palatalizacija *ky, *gy, *xy je na jugozahodu izpričana od 12., v severovzhodu in zahodu od 13. stoletja: Lpl *kyjixъ > киихъ (ok. 1120), Dpl *nebesbskyjimъ > певєсьскїмъ (1144), *kъnęgyńi > кмагими (1229), Dpl *někyjimъ > мћкимъ, Apl *porzdьniky > празаьмики (1282).

Praslovanski $* \boldsymbol{i}$ se je v večjem delu ukrajinščine velariziral in sovpadel z odrazom psl. *y (IGRJ: 126-127; IGUM: 160-162): psl. *i : *y > ukr. *y (psl. *lipa > rus. лúna [l'ipa], brus. лina [l'ipa], ukr. лйna [ly'pa]). Velarizacija psl. ${ }^{*} i$ je dokumentirana od 2. polovice 11. stoletja: *nepravbdy $>$ меправьаи, *prikryvajetb > прикривак, *ryba > рива (1073); *godiny > годым孔, *ryby > ривъы (1092). S to spremembo je najverjetneje v ukrajinščini povezana tudi

${ }^{16}$ Palatalizacije psl. ${ }^{*} k y,{ }^{*} g y,{ }^{*} x y>{ }^{*} k^{\prime} i,{ }^{*} g^{\prime} i,{ }^{*} x^{\prime} i$ ne izkazujejo nekateri severnoruski govori (RD 2013: 61). 
depalatalizacija soglasnikov (IGUM: $169-171$ ): psl. ${ }^{*} C^{E}>$ vsl. ${ }^{*} C^{\prime}>$ ukr. $C /$ $+\left[\right.$ psl. ${ }^{*} i, *_{e} / *_{b}>$ ukr. $\left.i, e\right]$ (psl. *nesti $>$ vsl. пести $>$ rus. нестиं [n'is't'i], brus. не́сиі [n’es'ci]], ukr. нести [nestỳ]).

Onezvenečenje izglasnih soglasnikov se je zgodilo v večjem delu ruščine in beloruščine ter v manjšem delu ukrajinščine (IGRJ: 116-117; GGBM: 104):

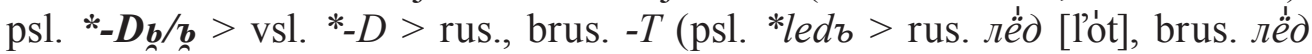
[l'ot], ukr. лід [l'id]). Pojav je izpričan od 13. stoletja: lat. Calendae $\rightarrow$ капантъ (1282); *otingdb > өтиноүть (1296).

Nesplošnovzhodnoslovanske glasovne značilnosti, ki so nastajale od 13. in 14. stoletja dalje (psl. ${ }^{*} u-/{ }^{*} Q_{-},{ }^{*} o_{-}>$nespl. rus., brus., ukr. vu-, vo-; psl. ${ }^{*}{ }^{2}>$ vsl. 'e $>$ nespl. rus., brus. $e$, SZ rus., ukr. $i$; psl. ${ }^{*} g>$ J rus., brus., ukr. $\gamma>h$; psl. ${ }^{*} o$, *e> J rus., brus. $a$, 'a (ojevsko in ejevsko akanje); psl. ${ }^{*} e^{*}{ }^{*} C^{\prime} a>\mathrm{S}$ rus.

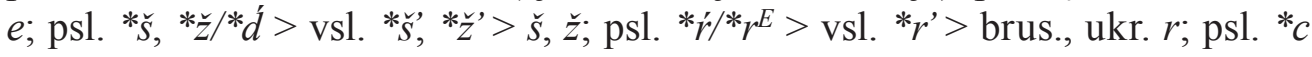
$\left[{ }^{*} \mathrm{c}^{\prime}\right]>$ vsl. ${ }^{*} c^{\prime}>$ rus., brus. $c$; psl. ${ }^{*} \check{c}\left[{ }^{*} \breve{c}^{\prime}\right]>\mathrm{Z}$ rus., brus. $\check{c}$; psl. ${ }^{*} v[\mathrm{u}]>\mathrm{S}$ rus. $v / f$, J rus., brus., ukr. v/u; psl. ${ }^{*} C b l C,{ }^{*} C b l C>$ vsl. ${ }^{*} C o l C>$ brus., ukr. Cou $C$ ), so še vedno ustvarjale precej obsežne areale ter so osnovne tri geolekte še dodatno razcepljale. Ker pa niso zaobjele tedaj že izoblikovanih treh geolektov v celoti (izjema je morda samo spreminjanje vsl. ${ }^{*}$ ColC $>$ brus., ukr. CouC), ne morejo biti genetska merila pri klasifikaciji vzhodne slovanščine na jezike.

\subsection{Ruščina, beloruščina, ukrajinščina}

Vzhodna slovanščina (11. stoletje) je nastala iz neenotnega izhodišča z vsaj petimi osnovnimi starejšimi vzhodnoslovanskimi geolekti (severovzhodna, novgorodsko-pskovska, pološko-smolenska, poleško-kijevska, jugozahodna vzhodna slovanščina) s konvergentnim razvojem v okviru splošnovzhodnoslovanskih inovacij. Pozneje sta se oblikovali dve inovativni središči, tj. severovzhodno (»rusko«) in jugozahodno (»ukrajinsko«), iz katerih so se širile mlajše nesplošnovzhodnoslovanske inovacije (12.-13. stoletje), pri čemer zahodno (»belorusko«) obrobje (ali samo njegov del) izkazuje inovacije obeh: 1) severovzhodno vzhodnoslovanske in jugozahodno vzhodnoslovanske dvostranske inovacije: a) psl. ${ }^{*} C R b C,{ }^{*} C R b C>$ vsl. $C R b C, C R b C>$ rus. ${ }^{*} C R o C,{ }^{*} C R e C$ : ukr. (in brus.) ${ }^{*} C R y C,{ }^{*} C R i C$; b) psl. ${ }^{*} b j,{ }^{*}{ }_{b j}>$ rus. ${ }^{*} e j,{ }^{*} o j$ : ukr. (in brus.) $*_{i j},{ }^{*} y j$; c) psl. $*_{e} / *_{b}>$ vsl. ${ }^{*} e>$ rus. (in brus.) 'o / $+\left[{ }^{\prime}{ }^{*} \mathrm{C}^{\mathrm{O}}, \#\right]$ : ukr. 'o / $+\left[{ }^{*}{ }^{2}, *_{z}, *^{*}, *_{\zeta}, *_{j}\right]$ ];

2) severovzhodno vzhodnoslovanska enostranska inovacija: psl. ${ }_{-}-D b / \underline{b}>$ vsl. *-D > rus. (in brus.) - $T$; 3) jugozahodno vzhodnoslovanski enostranski inovaciji: a) psl. $*_{e} C b / \bar{b}, *_{o} C b / \bar{b}>$ ukr. (in JZ brus.) $*_{e}, *^{*}$; b) psl. $*_{i}: *^{*}>$ ukr. $y$; c) psl. ${ }^{*} C^{E}>$ vsl. ${ }^{*} C$ ' $>$ ukr. $C /+\left[\right.$ _ psl. $*_{i}, *_{e} / *_{b}>$ ukr. $\left.i, e\right]$.

Mlajši vzhodnoslovanski geolekti hierarhične stopnje jezika so nastali iz starejših vzhodnoslovanskih geolektov ter imajo naslednji model lingvogeneze in definicijske lastnosti: 1) ruščina (severovzhodni vzhodnoslovanski jezik) ima neenotno izhodišče (severovzhodna in novgorodsko-pskovska vzhodna slovanščina) in konvergentno spreminjanje v okviru (samo)ruskih inovacij na severovzhodnem obrobju vzhodne slovanščine (psl. ${ }^{*} C R b C,{ }^{*} C R b C>$ rus. 
${ }^{*} C R o C,{ }^{*} C R e C$; psl. ${ }^{*} b j, *_{b j}>$ rus. *ej, *oj); 2) ukrajinščina (jugozahodni vzhodnoslovanski jezik) ima neenotno izhodišče (jugozahodna vzhodna in južni del poleško-kijevske vzhodne slovanščine) ter konvergentno spreminjanje v okviru (samo)ukrajinskih inovacij na jugozahodnem obrobju vzhodne slovanščine (psl.

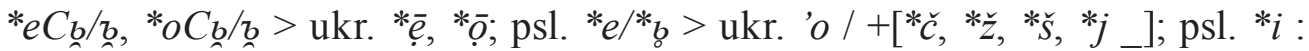
$* y>$ ukr. $y$; psl. ${ }^{*} C^{E}>$ ukr. $C /+\left[\ldots\right.$ psl. $*_{i}, *^{*} / *_{b}>$ ukr. $\left.\left.\left.i, e\right]\right) ; 3\right)$ beloruščina (zahodni vzhodnoslovanski jezik) ima neenotno izhodišče (pološko-smolenska in severni del poleško-kijevske vzhodne slovanščine) ter je prehodni geolekt na zahodnem obrobju vzhodne slovanščine, ki izkazuje del inovacij ruščine (psl. $*_{e} / *_{b}>$ vsl. $*_{e}>$ brus. ' $O /+\left[{ }_{-}{ }^{*} \mathrm{C}^{\mathrm{O}}, \#\right]$; psl. $*_{-} D \underline{b} / \mathrm{b}>$ brus. $\left.-T\right)$ in del inovacij ukrajinščine (psl. ${ }^{*} C R_{b} C,{ }^{*} C R_{b} C>$ brus. ${ }^{*} C R y C,{ }^{*} C R i C$; psl. ${ }^{*}{ }_{b j},{ }^{*}{ }_{b j}>$ brus.

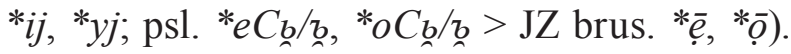

\section{LITERATURA}

IGUM - Алексей Петрович БЕСПАЛЬКО, Николай Каллиникович БОЙчУК, Михаил Андреевич ЖОВТОБРЮХ, Стефан Филиппович САМОЙЛЕНКО, Иван Иосифович ТАРАНЕНКО, ${ }^{2} 1962:$ Історична граматика української мови. Київ: Державне учбово-педагогічне видавництво »Радянська школащ.

IGRJ = Виктор Иванович БОРКОВСКИЙ, Петр Саввич КУЗНЕЦОВ, ${ }^{4} 2007$ ( $\left.{ }^{1} 1963\right)$ : Историческая грамматика русского языка. Москва: Издательство ЛКИ.

$\mathrm{BD}=$ Эвелина Даниловна БЛІНАВА, Евдокия Степанова МЯЦЕЛЬСКАЯ, ${ }^{2} 1980$ (1969): Беларуская дыялекталогія. Мінск: Выдавецтва »Вышэйшая школащ.

Karol DEJNA, 1981: Atlas polskich innowacji dialektalnych. Warszawa, Łódź: Państwowe wydawnictwo naukowe.

Макс ФАСМЕР, 1964, 1967, 1971, 1973: Этимологический словарь русского языка I-IV. Москва: Издательство »Прогресс«.

Федот Петрович ФИЛИН, 1972 (2006): Происхождение русского, украинского и белоруского языков. Москва: КомКнига.

Клавдия Васильевна ГОРШКОВА, 1972: Историческая диалектология русского языка. Москва: Просвещение.

GGBM = Федор Михайлович ЯНКОЎСКI, 1974: Гістарычная граматыка беларускай мовы 1: Уводзіны. Фанетыка. Мінск: Выдавецтва »Вышэйшая школа«.

Людмила Эдуардовна КАЛНЫНЬ, 1995: Рефлексация праславянского латерального сонанта $(* l)$. Восточнославянские изоглоссы 1. Москва: Наука. 14-20.

- -, 2000а: Отношение к признакам вокальность/консонантность в фонетике восточнославянских языков. Восточнославянские изоглоссы 3. Москва: Наука. 10-30.

- -, 2000b: Фонетические диалектные различия, обусловленные рефлексацией прасл. сочетаний плавных сонантов с редуцированными гласными. Восточнославянские изоглоссы 3. Москва: Наука. 31-38. 
Лінгвістычная геаграфія і групоўка беларускіх гаворак. Мінск: Академія навук БССР, Інстытут мовазнаўства імя Якуба Коласа, 1969.

Надежда Николаевна ПШЕНИЧНОВА, 1995: Гласные на месте редуцированных * $\breve{y}$ * *. Восточнославянские изоглоссы 1. Москва: Наука. 20-32.

Русская диалектология. Под редакцией Р. И. Аванесова и В. Г. Орловой. Москва: Академия наук СССР, Институт русского языка, 1964.

$\mathrm{RD}=$ Русская диалектология. Под редакцией Л. Л. Касаткина. Москва: Российская академия наук, Институт русского языка им. В. В. Виноградова, ${ }^{3} 2013$.

George Y. SHEVELOV, 1964: A Prehistory of Slavic: The Historical Phonology of Common Slavic. Heidelberg: Carl Winter Universitätsverlag.

--, 1979: A Historical Phonology of the Ukrainian Language. Heidelberg: Carl Winter Universitätsverlag. Ukrajinski prevod: Юрій ШЕВЕЛЬОВ, 2002: Історична фонологія украӥнської мови. Харків: АКТА.

Алексей Александрович ШАХМАТОВ, 1915: Очеркъ древнъйшаго періода исторіи русскаго языка. Петроградъ: Типографія Императорской академіи наукъ.

Matej ŠEKLI, 2013a: Genetolingvistična klasifikacija južnoslovanskih jezikov. Jezikoslovni zapiski 19/1, 71-99.

- -, 2013b: Genetic classification of West Slavic languages. Miklošičeva monografija: ob dvestoletnici rojstva Franca Miklošiča. Uredil Marko Jesenšek. Ljutomer: Gimnazija Franca Miklošiča. 101-115.

Александра Валерьевна ТЕР-АВАНЕСОВА, 1995: Рефлексы *'a и *е под ударением. Восточнославянские изоглоссы 1. Москва: Наука. 32-43.

- -, 2006: Рефлексы ё под ударением. Восточнославянские изоглоссы 4. Москва: Наука. 41-67.

Леонид Лазаревич ВАСиЛЬЕВ, 1929: О значении каморы в некоторых древнерусских памятниках XVI-XVII веков: к вопросу о произношении звука о в великорусском неречии. Сборник по русскому языку и словесности I/2. Ленинград.

Paul WEXLER, 1977: Historical Phonology of the Belorussian Language. Heidelberg: Carl Winter Universitätsverlag. Beloruski prevod (z dopolnjeno literaturo): Пол ВЭКСЛЕР, 2004: Гістарычная фаналогія беларускае мовы. Мінск: Выдавец І. П. Логвінаў.

Андрей Анатольевич ЗАЛИЗНЯК, ${ }^{2} 2004$ ('1995): Древненовгородский диалект. Москва: Языки славянской культуры.

Федор ЖИЛКО, ${ }^{1} 1955$ (21966): Нариси з діалектології украӥнської мови. Київ: Державне учбово-педагогічне видавництво »Радянська школащ. 


\section{GENETIC CLASSIFICATION OF EAST SLAVIC LANGUAGES}

East Slavic (ESl.) (11 ${ }^{\text {th }} \mathrm{c}$. AD) has a divergent starting point, characterized by at least five major older East Slavic geolects (i. e., North-Eastern, Novgorod-Pskov, Polock-Smolensk, Poles'e-Kijev, and South-Western East Slavic), which converged through a set of Common East Slavic innovations. For a later stage in the development of East Slavic two focal areas can be outlined. The North-Eastern (»Russian«) and South-Western (»Ukrainian«) areas thus came to represent two centres of spread of many younger non-Common-Slavic innovations $\left(12^{\text {th }}-13^{\text {th }}\right.$ centuries). The Western (»Belorussian «) margin (or possibly only a part of it), however, is typically characterized by innovations common to both areas: 1) North-Eastern East Slavic and South-Western East Slavic bilateral innovations: a) PSl. ${ }^{*} C R \_C,{ }^{*} C R b C>$ ESl. $C R b C, C R b C>$ Russ. ${ }^{*} C R o C,{ }^{*} C R e C$ : Ukr. (and Bruss.) ${ }^{*} C R y C,{ }^{*} C R i C$; b) PSl. ${ }_{b j},{ }^{*}{ } j j>$ Russ. ${ }^{*} e j,{ }^{*} o j$ : Ukr. (and Bruss.) *ij, *yj; c) PSl.

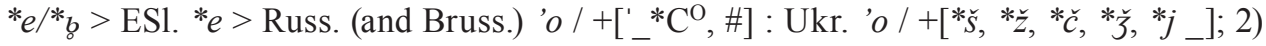
North-Eastern East Slavic unilateral innovation: PSl. *-Db/b $>$ ESl. $*_{-} D>$ Russ. (and Bruss.) -T; 3) South-Western East Slavic unilateral innovations: a) PSl. ${ }^{*} C \mathrm{Cb} / \mathrm{z},{ }^{*} o C_{b} / \mathfrak{b}>$ Ukr. (and SW Bruss.) $*_{\bar{e}},{ }^{*} \bar{o}$; b) PSl. ${ }^{*} i:{ }^{*} y>\mathrm{Ukr} . y$; c) PSl. ${ }^{*} C^{E}>\mathrm{ESl} .{ }^{*} C^{\prime}>\mathrm{Ukr} . C /$ $+\left[\right.$ PSSl. $*_{i}, *_{e} / *_{b}>$ Ukr. $\left.i, e\right]$.

Younger East Slavic geolects were formed on the basis of older East Slavic geolects. According to their defining characteristics, the following models of their linguogenesis can be established: 1) Russian (i. e., North-Eastern East Slavic language) has a divergent starting point (North-Eastern and Novgorod-Pskov East Slavic) and is further characterized by convergent Russian innovations of the North-Eastern margins of East Slavic (PSl. ${ }^{*} C R_{b} C,{ }^{*} C R b C>$ Russ. ${ }^{*} C R o C,{ }^{*} C R e C$; PSl. ${ }^{*} b j,{ }^{*} b j>$ Russ. ${ }^{*} e j$, ${ }^{*} o j$ ); 2) Ukrainian (i.e., South-Western East Slavic language) has a divergent starting point (South-Western and southern part of Poles'e-Kijev East Slavic) and is subsequently characterized by (convergent) Ukrainian innovations of the South-Western margins of

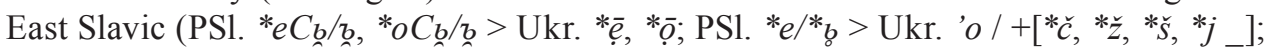
PSl. $*_{i}:{ }^{*} y>$ Ukr. $y$; PSl. ${ }^{*} C^{E}>$ Ukr. $C /+\left[\right.$ [ PSl. $*_{i}, *^{*} /{ }^{*} b>$ Ukr. $\left.\left.\left.i, e\right]\right) ; 3\right)$ Belorussian (i. e., Western East Slavic) has a divergent starting point (Polock-Smolensk and northern part of Poles'e-Kijev East Slavic) and represents a transitional geolect on the western margins of East Slavic, displaying a set of innovations typical of Russian (PSl. $*_{e} / *_{b}>$ ESl. ${ }^{*} e>$ Bruss. ' $o /+\left[{ }_{-}{ }^{*} \mathrm{C}^{\mathrm{O}}\right.$, \#]; PSl. ${ }^{*} D_{b} / \bar{b}>$ Bruss. $-T$ ) as well as Ukrainian (PSl.

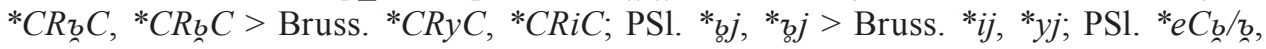
$*_{o} C_{b} / \mathfrak{b}>$ SW Bruss. *ēe, *ō). 